\title{
Evaluation of Preoperative Nutritional Status Using Subjective Global Assessment (SGA) Score in Predicting Postoperative Outcome in Patients Undergoing Gastrointestinal Anastomosis
}

\author{
Dr. C. Gangalakshmi ${ }^{1}$, Dr. Mohamed Aabrez Shams ${ }^{2}$ \\ ${ }^{1}$ Assistant Professor, Department Of General Surgery, Madurai Medical College, Madurai, Tamilnadu, India. \\ ${ }^{2}$ Postgraduate, Department Of General Surgery, Madurai Medical College, Madurai, Tamilnadu, India.
}

\begin{abstract}
Gastrointestinal anastomosis is one of the most common procedures performed for a widevariety of surgical conditions either as the primary treatment or as part of a major surgerysuch as cancer surgery to restore anastomosis following resection. Despite meticuloustechnique, anastomotic surgeries tend to have frequent complicationsranging from issuesas simple as anaemia following surgery to requiring ventilatory support and repeatsurgery for their management. This study aims to evaluate the efficacy of the SubjectiveGlobal Assessment (SGA) Score in predicting postoperative morbidity in patientsundergoing these surgeries depending on their preoperative nutritional status. The Subjective Global Assessment Score is a valuable tool in predictingpostoperative complications in patients undergoing anastomotic surgeries and will enableus to provide perioperative nutritional support to patients who are prone to complications, thereby reducing wastage of human and monetary resources.
\end{abstract}

Keywords: Gastrointestinal anastomosis, Subjective Global Assessment, SGA score.

\section{Introduction}

Gastrointestinal anastomosis forms a major portion of procedures being done ingeneral surgery department in the elective setting. Postoperative complications such asanastomotic leak hence morbidity and mortality are very much prevalent in such cases due to nutritional status of these patients. This in turn leads to elevation in the cost involved in postoperative management of these patients and thereby overall health-related expenditure of the State. Routine pre-operative assessment of patients is usually based on BMI which is not reliable owing to adaptation of the patient's body to chronic starvation - such patients appear to have a better post-operative outcome when compared to seemingly healthy patients. Subjective Global Assessment (SGA) score is a simple and effective method of assessing the pre-operative nutritional status of patients which helps in correcting the nutritional deficit before taking the patient for surgery. This in turn will help in reducing the morbidity and mortality associated with major gastrointestinal surgeries involving anastomosis and also the overall expenditure associated with health care in the Government set up.

\section{Aims Of The Study}

To assess the efficacy of Subjective Global Assessment (SGA) score in correlatingpreoperative nutritional status with postoperative outcome in patients undergoinggastrointestinal anastomosis surgeries.

\section{Objectivesof the study}

1. To assess the preoperative nutritional status of patients undergoing electivegastrointestinal anastomosis surgeries using a subjective global assessment (SGA) score, determined by medical history and clinical findings.

2. To use this score in predicting postoperative outcome in these patients.

3. To utilize the Subjective Global Assessment (SGA) score to select patients at high riskfor postoperative complications and to provide perioperative nutritional support to thesepatients.

4. To reduce the health-care costs associated with adverse postoperative outcomes inpatients undergoing elective gastrointestinal anastomosis surgeries.

\section{Eligibility Criteria}

A. Inclusion criteria:

1. Patients - Age between 16 and 80 years in both sexes.

2. All patients undergoing elective Gastrointestinal surgeries involving bowel anastomosis.

3. Patients who consented for inclusion in the study according to designated proforma. 
B. Exclusion criteria:

1. Patients undergoing emergency Gastrointestinal surgeries and major elective surgeriesother than Gastrointestinal surgeries.

2. Patients who refused to give informed written consent.

\section{Materials And Methods}

1. Patients subjected to this study were taken from surgical units of Government RajajiHospital, Madurai over a period of 6 months from January 2016 to June 2016.

2. 50 patients underwent Gastrointestinal anastomosis surgeries (34 males and 16 females) for various bdominal conditions.

3. Factors such as age, sex, weight loss, anorexia, vomiting, diarrhea, fat wasting, muscleasting, oedema and ascites were taken into account.

4. Patients were investigated with Haemoglobin, Serum Protein, Complete blood count,blood sugar, renal function test and ultrasonogram of abdomen and pelvis.

5. Patients were classified into 3 groups - A, B \& C, based on their preoperative nutritional status using Subjective Global Assessment Score.

6. Patients were operated upon by experienced surgeons and Gastrointestinal anastomosissurgeries were done for their conditions.

7. The incidence of post-operative morbidity was assessed in each group of patients and its correlation with preoperative nutritional status as predicted by the SGA score was observed.

\section{Observation Of The Study}

The study included 50 patients of whom 39 were male patients and 11 were female patients. The patients were attending the surgical out-patients department of Government Rajaji Hospital, Madurai. Among the 50 cases, the common age group of patients was between 46-60 years followed by patients between 31-45 years. Least incidence of requirement of surgery was found in young patients below 30 years of age. The observations and results of the study are depicted in the following tables.

\section{AGE DISTRIBUTION}

\begin{tabular}{|l|l|l|}
\hline AGE. & $\begin{array}{l}\text { No. of } \\
\text { Cases }\end{array}$ \\
\hline$<30$ & 6 & 12.00 \\
\hline $31-45$ & 13 & 26.00 \\
\hline $46-60$ & 21 & 42.00 \\
\hline$>60$ & 10 & 20.00 \\
\hline Total & 50 & 100.00 \\
\hline
\end{tabular}

AoE Distrebunion

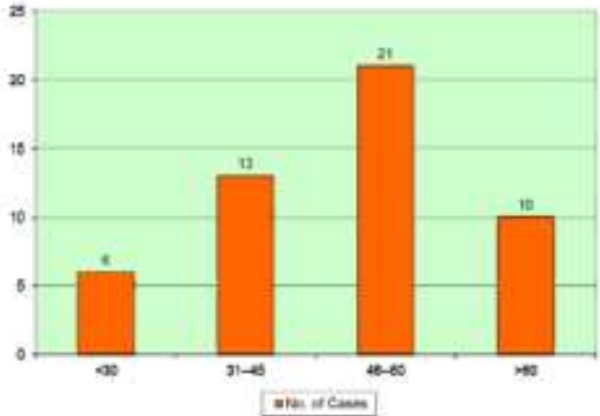

Sex Distribution

\begin{tabular}{|l|l|l|l|}
\hline Sex vs & Yes & No & Total \\
Morbitity & & & \\
\hline MALE & 18 & 21 & 39 \\
\hline FEMALE & 5 & 6 & 11 \\
\hline Total & 23 & 27 & 50 \\
\hline
\end{tabular}

sexostriautos
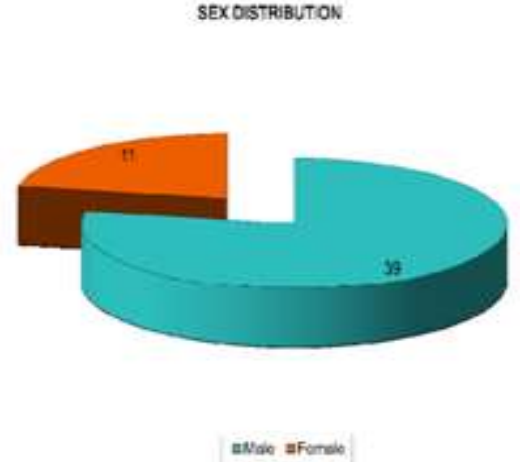

Procedures Performed 
Evaluation Of Preoperative Nutritional Status Using Subjective Global......

\begin{tabular}{|c|c|c|}
\hline Procedure & No. of Cases & $\%$ \\
\hline A.PR & 3 & 6.00 \\
\hline Coloplasty & 1 & 2.00 \\
\hline Distal Gestrectomy & 6 & 12.00 \\
\hline Gastrojejunostomy & 7 & 14.00 \\
\hline Ileotransverse snas & 2 & 4.00 \\
\hline Limited resection & 1 & 2.00 \\
\hline Low anterior resec & 1 & 2.00 \\
\hline Lt. Hemicolectomy & 2 & 4.00 \\
\hline Oesophagojejunos & 3 & 6.00 \\
\hline Polliative bypsss & 6 & 6.00 \\
\hline Resection ansstom & & 12.00 \\
\hline
\end{tabular}

\begin{tabular}{|c|c|c|}
\hline Rt. Hemicolectomy & 7 & 14.00 \\
\hline Stoms takedown & 4 & 8.00 \\
\hline Total Gastrectomy & 2 & 4.00 \\
\hline Whipple's procedu & 2 & 4.00 \\
\hline Total & 50 & 100.00 \\
\hline
\end{tabular}

\section{Procedure Performed}

\section{PROCEDURE}

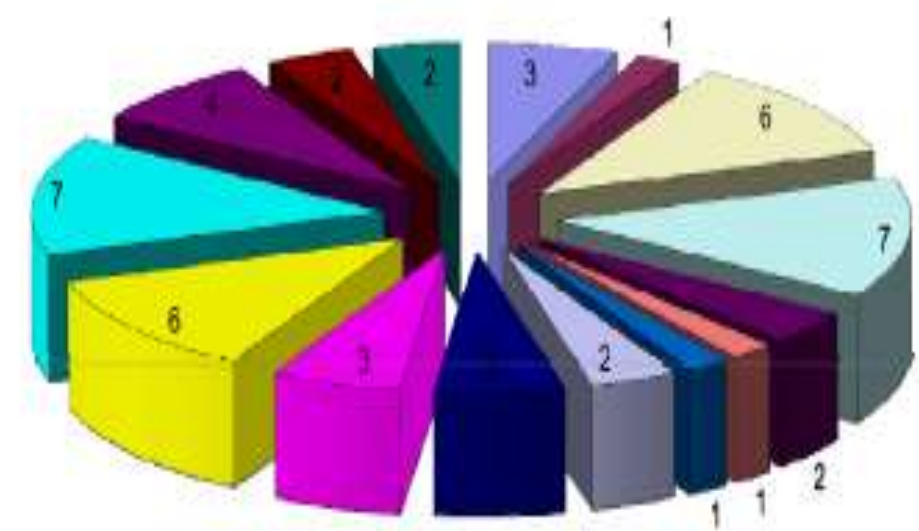

\begin{tabular}{|c|c|c|c|c|}
\hline aAFR & cóluplasty & aDsal Gratiedum! & DGstrquejrosiany & - lecolrailswese anas \\
\hline aumiles iosection. & a Low andrie fesetc & alt Hemitalectorny & - Owechtrajpjejunes & apsiative bapass \\
\hline QRescion arasium & aRt. Henvodesiony & -Sicma takedown & -Tosi Gatiechom & n'Muppers procedu \\
\hline
\end{tabular}

Conditions For Which Anastomosis Was Done 


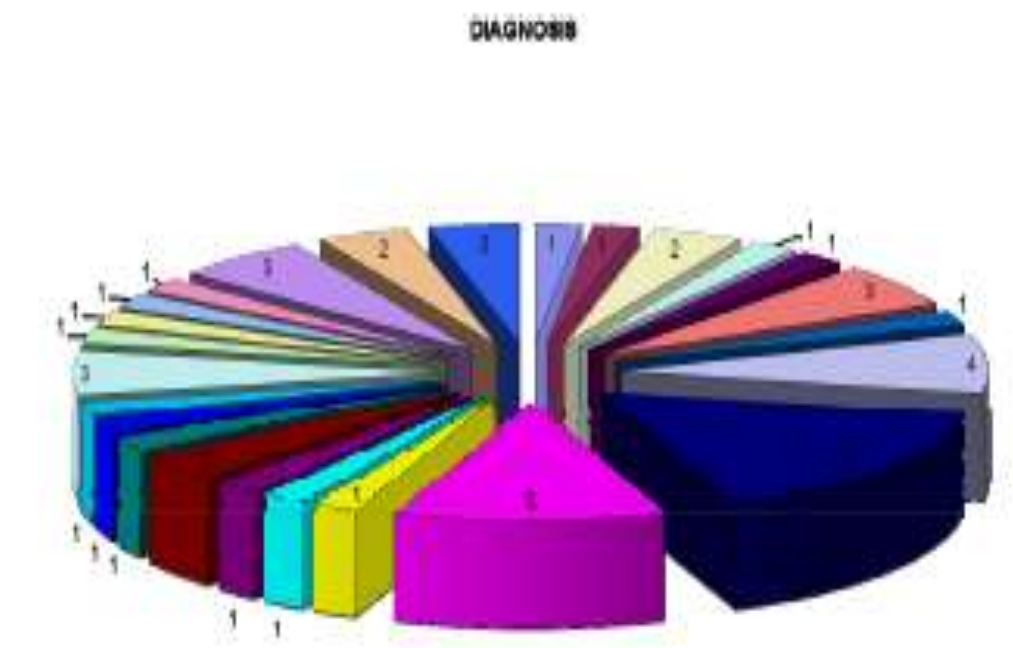

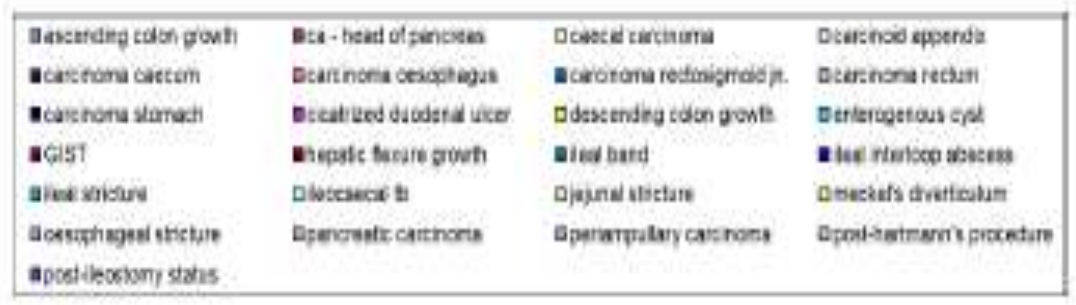

\section{Discussion Of The Study}

In the study conducted, 50 patients were included out of which 39 patients were male and

11 patients were female patients.Patients most commonly belonged to 46-60 years age group which included $42 \%$ ofpatients followed by $26 \%$ of patients belonging to $31-45$ years age group. The least occurrencewas seen in less than 30 years age group.The commonest symptom that occurred in the patients was weight loss which was seen in 41 out of 50 patients constituting $82 \%$ of the study group.Other clinical features included anorexia seen in $72 \%$ of patients, fat loss in $54 \%$, vomitingseen in $48 \%$, diarrhea seen in $40 \%$, muscle wasting in $28 \%$, oedema in $18 \%$, least commonbeing ascites seen in $14 \%$ of patients.The incidence of vomiting was seen to be higher in patients having upper gastrointestinalpathology while diarrhea was more common in patients with colonic and distal small intestinaldisorders. The commonest condition seen in the patients was Carcinoma Stomach which was thediagnosis in 8 patients out of 50 , constituting $16 \%$ of the study group.

The most frequently performed procedures were Gastrojejunostomy and RightHemicolectomy which were performed in 7 patients each, constituting $14 \%$ each of the totalstudy group.There was no significant difference in the incidence of postoperative morbidity in maleand female patients.The importance of preoperative BMI in the study group has been observed to be significant with all patients belonging to low BMI of less than 18.5 developing complications postoperatively compared to less than $20 \%$ of patients with normal BMI developing morbidity.Coming to the most important aspect of the study which is the Subjective GlobalAssessment score: out of 14 patients who belonged to the well nourished SGA Group A, only 1 patient was found to have developed postoperative morbidity, namely requirement of postoperative blood transfusion.One third of patients, namely 7 out of 21 patients belonging to the moderately nourishedGroup B, developed postoperative complications. Out of the 7 patients, 3 of them required blood transfusions, 2 patients required fresh frozen plasma and albumin transfusion, 1 patient required ventilator support and 1 patient developed anastomotic leak which was managed conservatively.

In the study group, 15 patients belonged to SGA Group C or the poorly nourished group.Of these, all 15 patients developed postoperative morbidity and required prolonged intensive care and hospital stay. 8 out of 15 patients required both blood and fresh frozen plasma transfusions for a minimum of 3 days and a maximum of 5 days. 3 patients developed postoperative anastomotic leak of which 2 patients had to be reoperated and stoma was created. 4 patients requiredventilatory support for a minimum of 2 days and maximum of 6 days. 10 out of these 15 patients developed postoperative wound infection. 


\section{Conclusion}

The study was successfully completed and the Subjective Global Assessment scoreproved to be $100 \%$ successful in predicting postoperative morbidity in poorly nourishedpatients. The study shows the correlation between preoperative nutritional status of patientsundergoing gastrointestinal anastomotic surgeries and the corresponding postoperativemorbidity in these patients.Thus, the Subjective Global Assessment score is a valuable tool in predicting theoccurrence of postoperative complications in patients whose preoperative nutritional status is below optimum level. Implementing this scoring system routinely in our wards prior to taking up patients for major surgeries and optimizing the nutritional status (improving status from Group C to Group A) with preoperative nutritional support will reduce the incidence of adverse outcomes in patients and will consequently reduce the health related monetary as well as resource expenditure of the State.

\section{References}

[1]. Nadamuni NN, Prahlad Rao N. Body mass index: a measure of nutritional status in

[2]. Indian population. Eur J Clin Nutr 1994;48 (Suppl 3):S131-S140.

[3]. Indian Council of Medical Research. National Nutrition Monitoring Bureau Report for

[4]. the Year 1996: Rural Sur- veys. Hyderabad: National Institute for Nutrition. 1996.

[5]. Neumayer LA, Smout RJ, Horn HG, Horn SD. Early and sufficient feeding reduces

[6]. length of stay and charges in sur? gical patients. J Surg Res 2001;95:73-7.

[7]. Heys SD, Walker LG, Smith I, Eremin O. Enteral nutritional supplementation with key

[8]. nutrients in patients with critical illness and cancer: a meta-analysis of randomized controlled clinical trials. Ann Surg 1999;229:467-77.

[9]. Smedley F, Bowling T, James M, Stokes E, Goodger C, O’Connor O, et al. Randomized clinical trial of the effects of preoperative and postoperative oral nutritional supplements on clinical course and cost of care. Br J Surg 2004;91:983 90.

[10]. Potter J, Langhome P, Roberts M. Routine protein energy supplementation in adults: systematic review. Br Med J 1998;317:495501.

[11]. Lewis SJ, Egger M, Sylvester PA, Thomas S. Early enteral feeding versus "nil by

[12]. mouth" after gastrointestinal surgery: systematic review and meta-analysis of controlled trials. Br Med J 2001;323:773-6.

[13]. Jones JM. The methodology of nutritional screening and as $\neg$ sessment tools. J Hum Nutr Diet 2002;15:59-71

[14]. Kondrup J, Allison SP, Elia M, Vellas B, Plauth M, and the Educational and Clinical

[15]. Practice Committee, European Soci $\neg$ ety of Parenteral and Enteral Nutrition (ESPEN). ESPEN guidelines for nutrition screening 2002. Clin Nutr 2003; 22: 415-21.

[16]. ASPEN Board of Directors and the Clinical Guidelines Task Force. Guidelines for the use of parenteral, enteral nutrition in adult and pediatric patients. J Parenteral Enteral Nutr 2002;26:1SA-138SA.

[17]. Soares MJ, Shetty PS. Basal metabolic rates and metabolic economy in chronic

[18]. undernutrition. Eur J Clin Nutr 1991;45:363า 73.

[19]. Jeejeebhoy KN. Clinical and functional assessments. In: Shils ME, Olson JA, Shike M, Eds. Modern Nutrition in Health and Disease, 8th ed. Philadelphia: Lea and Febiger. 1994: p.805-11.

[20]. Detsky AS, Baker JP, Mendelson RA, Wolman SL, Wesson DE, Jeejeebhoy KN.

[21]. Evaluating the accuracy of nutritional assessment techniques applied to hospitalized patients:methodology and comparisons. $\mathrm{J}$ Parenter Enteral Nutr 1984;8:153ᄀ9.

[22]. Detsky AS, McLaughlin JR, Baker JP, Johnston N, Whittaker S, Mendelson RA, et al. What is subjective global assessment of nutritional status? J Parenter Enteral Nutr

[23]. 1987;11:8ᄀ 13.

[24]. Persson C, Sjoden PO, Glimelius B. The Swedish version of the patient-generated

[25]. Subjective global assessment of nutritional status: gastrointestinal vs urological cancers. Clin Nutr 1999;18:71-7.

[26]. Julien JP, Combe C, Lasseur C. Subjective global assessment of nutrition a useful

[27]. diagnostic tool for nurses? EDTNA ERCA J 2001;27:193-6.

[28]. Stephenson GR, Moretti EW, El-Moalem H, Clavien PA, Tuttle- Newhall JE.

[29]. Malnutrition in liver transplant patients: preop $\neg$ erative subjective global assessment is

[30]. predictive of outcomes after liver transplantation. Transplantation 2001;72:666-70.

[31]. Sacks GS, Dearman K, Replogle WH, Cora VL, Meeks M, Canada T. Use of subjective global assessment to identify nutritionassociated complications and death in geriatric long-term care facility residents. J Am Coll Nutr 2000;19:570-7. 


\section{Proforma}

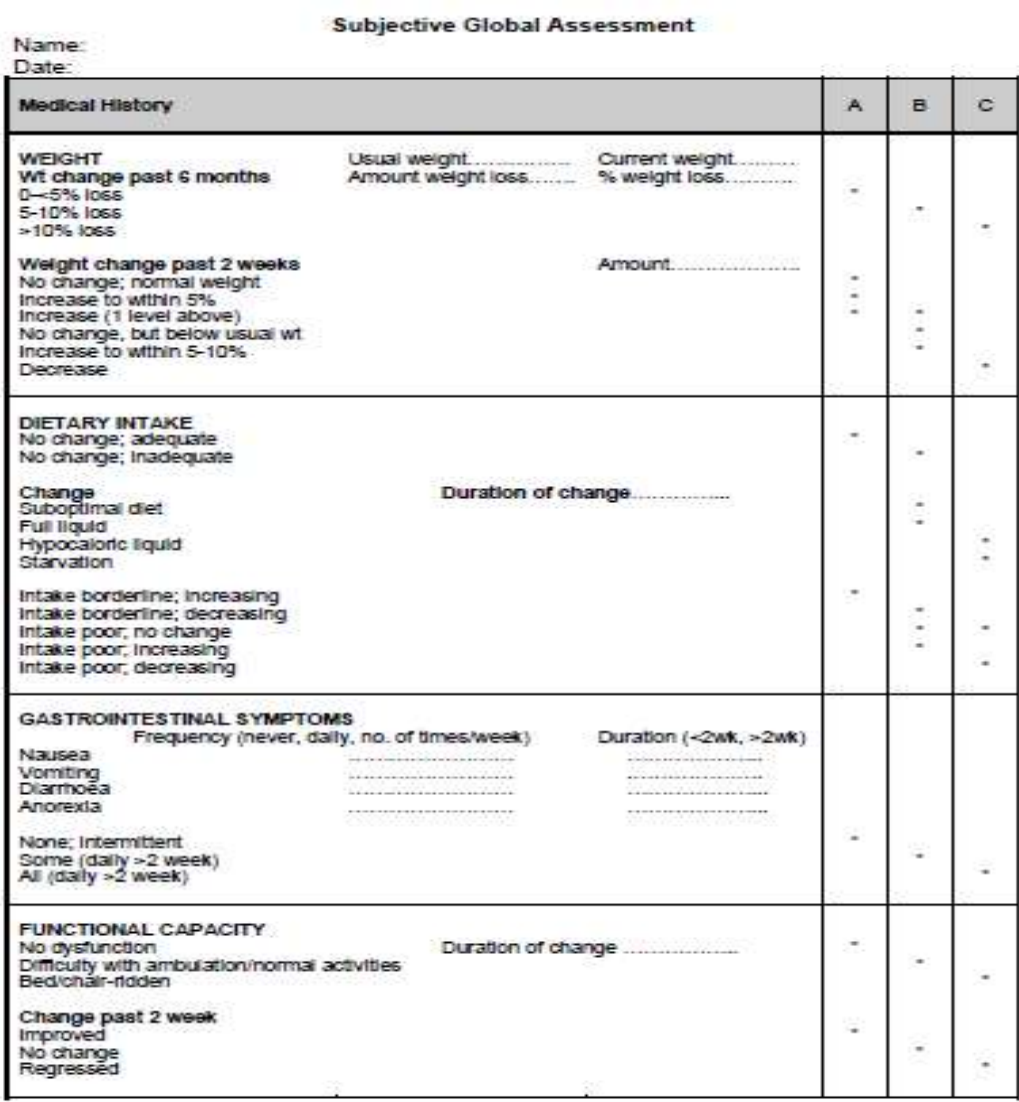

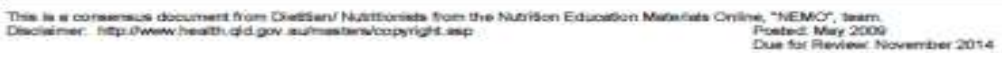

\begin{tabular}{|c|c|c|c|}
\hline Phvalcal examination & A & B & c \\
\hline \multicolumn{4}{|l|}{ SUBCUTANEOUS FAT } \\
\hline Under the eyes & sighty buiging area & & $\begin{array}{l}\text { Holiowed lock. } \\
\text { depression, dark }\end{array}$ \\
\hline Triceps & $\begin{array}{l}\text { Large space between } \\
\text { ingers }\end{array}$ & & $\begin{array}{l}\text { Very litte space } \\
\text { Detween ningers, or } \\
\text { nngers touch }\end{array}$ \\
\hline Biceps & $\begin{array}{l}\text { Large space detween } \\
\text { fingers }\end{array}$ & & $\begin{array}{l}\text { Very intle space } \\
\text { Dehween nngers, or } \\
\text { nngers touch }\end{array}$ \\
\hline \multicolumn{4}{|l|}{ MUSCLE WASTING } \\
\hline Temple & $\begin{array}{l}\text { Well-detned } \\
\text { musclenat }\end{array}$ & sigm depression & Hollowing. \\
\hline Clavide & $\begin{array}{l}\text { Not velbie in Males; } \\
\text { may De visible but not } \\
\text { prominent in semales }\end{array}$ & $\begin{array}{l}\text { Some protrusion; } \\
\text { may not be alt the } \\
\text { way aiong }\end{array}$ & $\begin{array}{l}\text { Protruding prominent } \\
\text { Done }\end{array}$ \\
\hline Shoulder & Rounded & $\begin{array}{l}\text { Noo square look } \\
\text { acromion process } \\
\text { may protrude }\end{array}$ & $\begin{array}{l}\text { Square look bones } \\
\text { prominert. }\end{array}$ \\
\hline scapularios & $\begin{array}{l}\text { Bones not prominent: } \\
\text { no slgnificant } \\
\text { depressions }\end{array}$ & $\begin{array}{l}\text { signtily } \\
\text { Mild depressions or } \\
\text { bone may show } \\
\text { silghny. not all }\end{array}$ & $\begin{array}{l}\text { Bones prominent } \\
\text { signincart } \\
\text { oepressions }\end{array}$ \\
\hline Guadnceps & $\begin{array}{l}\text { Wel rounded; no } \\
\text { depressions }\end{array}$ & Mid depression & Depression; thin \\
\hline Cait & well developed & & Thin no muscie \\
\hline knee & Bones not prominent & & Bones prominent \\
\hline $\begin{array}{l}\text { interossecus muscie between } \\
\text { gurmb and forennger }\end{array}$ & $\begin{array}{l}\text { Muscle protrudes: } \\
\text { coula be nat in femiles }\end{array}$ & & $\begin{array}{c}\text { Fiat or depressed } \\
\text { area } \\
\end{array}$ \\
\hline OEDEMA (related to malnutrition) & No sign & Mild to moderate & Severe \\
\hline ASCrTES (related to mainutrition\}) & No sign & Mild to moderate & severe \\
\hline OVERALL SGA RATING & A & B & c \\
\hline
\end{tabular}

Adapted from: Detsky et al., 1994". Baxter Healthcare Corporation, 1993; McCann, 1996 (Ferguson, Bauer, Banks, Capra, 1996)e

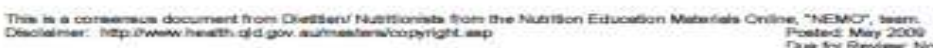

